\title{
Histochemical demonstration of gamma glutamyl transpeptidase activity in bone marrow and blood cells
}

\author{
STANISLAW SZMIGIELSKI, JOANNA LITWIN, AND BARBARA ZUPANSKA \\ From the Department of Clinical Haematology, \\ State Institute of Haematology, Warsaw, Poland
}

SYNOPSIS The demonstration by a histochemical method of gamma glutamyl transpeptidase is described. In marrow and peripheral blood it has been found useful in differentiating between normal and leukaemic myeloblasts and between marrow (short-lived) lymphocytes and lymph node (long-lived) lymphocytes. The method may also be of value in differentiating between normal and neoplastic cells.

Gamma-glutamyl transpeptidase (G.G.T.P.) is an enzyme catalysing the transformation of $\gamma$-glutamyl molecules in suitable peptides. Orlowski (1963) established that glutathion is the physiological donor of $\gamma$-glutamyl molecules, and that G.G.T.P. can catalyse both the synthesis and breakdown of $\gamma$-glutamyl peptides, in this respect differing from other peptidases. The course of the reaction is dependent on the concentration of $\gamma$-glutamyl group donors and acceptors (Orlowski, 1963). For the demonstration of G.G.T.P. activity many methods have been proposed (Fodor, Miller, Neidle, and Waelsch, 1953; Kinoshita and Ball, 1953; Sullivan and Hess, 1936), with the use of glutathion as the substrate, but none of them was fit for histochemical investigation. The synthesis of $\mathrm{N}$ - $(\gamma$-L-glutamyl)- $\alpha$-naphthylamide and $\mathrm{N}$ - $(\gamma$-L-glutamyl) $-\beta$-naphthylamide has made possible the localization in tissue of G.G.T.P. (Glenner, Folk, and McMillan, 1962). From these Received for publication 25 September 1964. two substrates the former has been shown as the better for histochemical procedures (Glenner et al., 1962). Gamma-glutamyl transpeptidase activity has been demonstrated in various human and animal organs, including kidneys, liver, and spleen (Glenner et al., 1962; Orlowski, 1963) but investigation of its activity in normal and pathological bone marrow and peripheral blood cells has not been determined before.

\section{MATERIAL AND METHODS}

Gamma-glutamyl transpeptidase activity was demonstrated with the use of the modified technique described previously(Albert, Orlowski, and Szewczuk, 1961 ; Glenner et al., 1962), when $\mathrm{N}-/ \gamma$-L-glutamyl/- $\alpha$-naphthylamide was used as the substrate. Bone marrow and blood smears were air dried for two hours, fixed for four minutes in cold $\left(4^{\circ} \mathrm{C}\right.$.) formalin vapour, carefully rinsed in distilled water, and incubated for two hours at $20^{\circ} \mathrm{C}$. in the following solution:-

TABLE I

GAMMA GLUTAMYL TRANSPEPTIDASE ACTIVITY IN BONE MARROW AND BLOOD CELLS OF NORMAL ADULTS

\begin{tabular}{|c|c|c|c|}
\hline Bone Marrow & Activity & Peripheral Blood & Activity \\
\hline $\begin{array}{l}\text { Pronormoblast } \\
\text { Basophilic normoblast } \\
\text { Polychromatophilic normoblast } \\
\text { Orthochromic normoblast } \\
\text { Myeloblast } \\
\text { Progranulocyte } \\
\text { Myelocyte } \\
\text { Metamyelocyte } \\
\text { Band granulocyte } \\
\text { Segmented granulocyte } \\
\text { Lymphocyte } \\
\text { Reticulum cell } \\
\text { Lymphoid reticulum cell } \\
\text { Plasmacyte } \\
\text { Megakarocyte }\end{array}$ & $\begin{array}{l}+ \\
+(100 \%) \\
+(50 \%) \\
+ \\
+ \\
++ \\
+ \\
+ \\
+ \\
70 \cdot 2 \% \pm 20.4 \% \\
18 \cdot 2 \% \pm 12.6 \% \\
++ \\
+ \\
+(60.3 \%) \\
+\end{array}$ & $\begin{array}{l}\text { Granulocytes } \\
\text { Lymphocytes }\end{array}$ & $\begin{array}{l}82.1 \% \pm 12.8 \% \\
78.6 \% \pm 18.2 \%\end{array}$ \\
\hline
\end{tabular}


Substrate in acetone $(6 \mathrm{mg} . / \mathrm{ml}.) \ldots \ldots \ldots .0 .5 \mathrm{ml}$.

Fast Garnet GBC salt $(15 \mathrm{mg} . / \mathrm{ml}.) \quad \ldots \ldots 1.0 \mathrm{ml}$.

Tris $\mathrm{HCl}$ buffer $(p \mathrm{H} \mathrm{7.2}) \ldots \ldots \ldots \ldots \ldots .10 .0 \mathrm{ml}$.

Distilled water $\ldots \ldots \ldots \ldots \ldots \ldots \ldots .28 .5 \mathrm{ml}$.

Methionine .................... $0.03 \mathrm{~g}$.

The solution was prepared immediately before use, and after incubation the smears were stained for 10 minutes with $0.5 \%$ aqueous Azur II.

Bone marrow and blood smears from 15 healthy adults and 45 subjects suffering from various haematological disorders were investigated.

\section{RESULTS}

The results are summarized in Tables I and II. NORMAL ADULTS Gamma-glutamyl transpeptidase activity was visible in all pro-erythroblasts and basophilic normoblasts $(++)$, as well as in the considerable number of polychromatophilic normoblasts $(50 \%)$ but none was established in orthochromatic normoblasts. Activity was observed in all normal myeloblasts $(+)$, promyelocytes $(++)$, and myelocytes $(+++)$ (Fig. 1) and 62-100\%, (mean $77 ; 2 \%$ ) of mature granulocytes showed marked enzyme activity (Fig. 2). Only $2-10 \%$ of the lymphocytes in bone marrow were noticed as G.G.T.P.positive cells; however, all reticulum cells, including plasma cells, showed marked activity (Fig. 3). In about $60 \%$ of normal plasma cells enzyme activity ranged from + to ++ (Fig. 4). In peripheral blood 57$100 \%$ (mean $76.6 \%$ ) of mature granulocytes and $63-100 \%$ (mean $74.6 \%$ ) of lymphocytes showed G.G.T.P. activity. Leukaemic myeloblasts, compared with normal stem cells, showed a marked increase in G.G.T.P. activity (Fig. 5). In neoplastic plasma cells decreased enzyme activity was observed, expressed both as diminished intensity of reaction and in the number of active cells. Investigations in peripheral blood from subjects with haemotological disease gave no concrete results (Tables I and II).

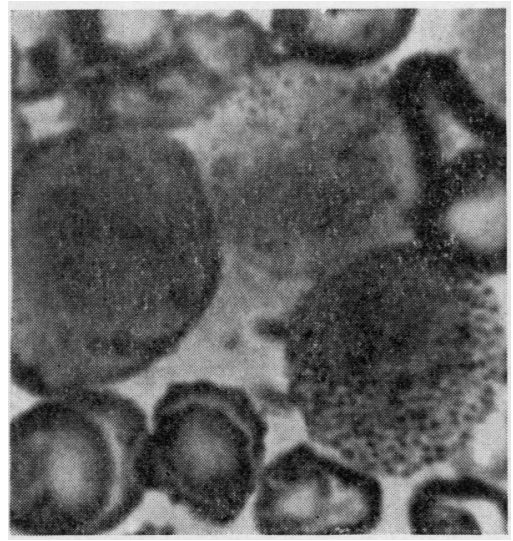

iIG. 1.

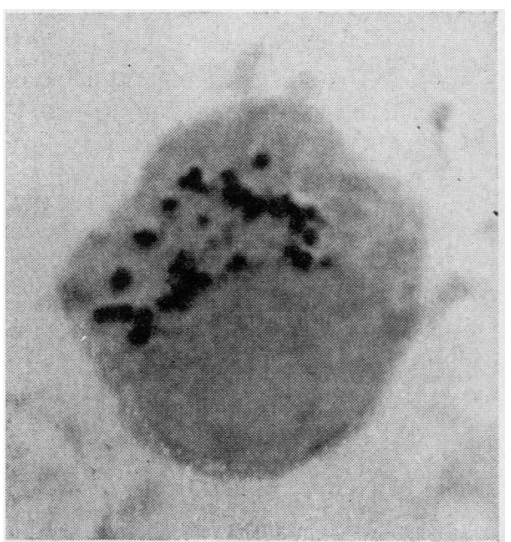

FIG. 4.

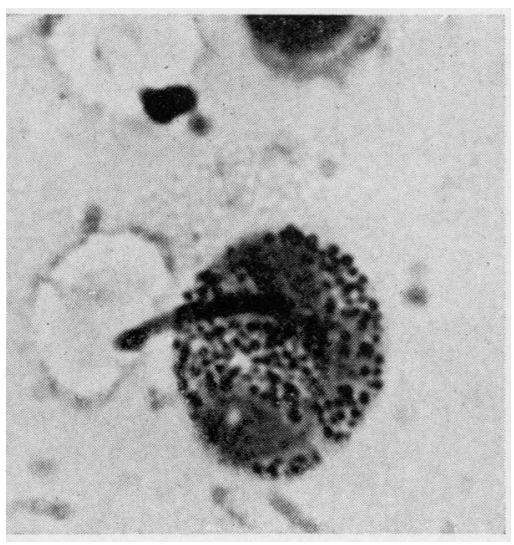

FIG. 2.

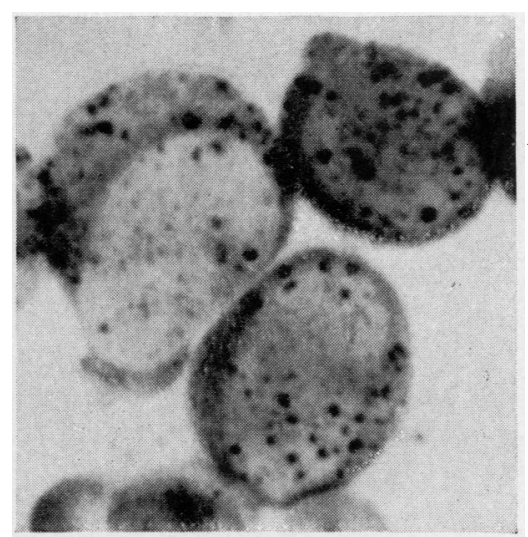

FIG. 5.
FIG. 3 .

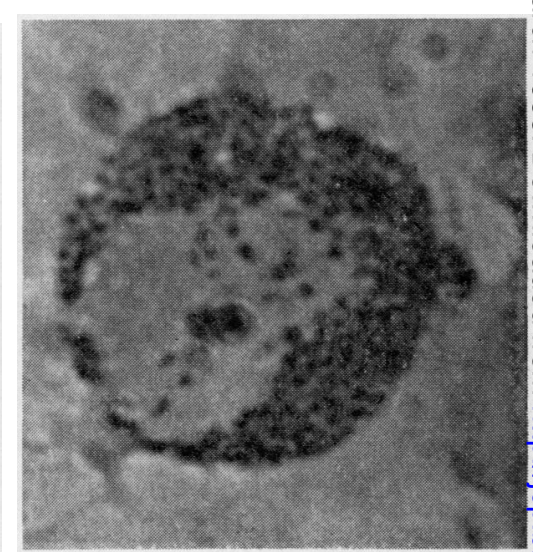

FIG. 1. G.G.T.P. activity in myeloblasts, premyelocytes, and myelocytes.

FIG. 2. Active mature granulocyte and negative bone marrow lymphocyte.

FIG. 3. Active reticulum cells.

FIG. 4. G.G.T.P. activity in normal plasma cell.

FIG. 5. Strong enzyme activity in leukaemic myeloblasts. 


\section{TABLE II}

ENZYME ACTIVITY IN PATHOLOGICAL PERIPHERAL BLOOD

\begin{tabular}{|c|c|c|c|c|}
\hline \multirow[b]{2}{*}{ Diagnosis } & \multirow[b]{2}{*}{$\begin{array}{l}\text { No. of } \\
\text { Cases }\end{array}$} & \multicolumn{2}{|c|}{ G.G.T.P. Activity } & \multirow[b]{2}{*}{ Cells } \\
\hline & & Normal & Decreased & \\
\hline $\begin{array}{l}\text { Acute myeloblastic } \\
\text { leukaemia }\end{array}$ & 6 & $\begin{array}{l}3 \\
4\end{array}$ & $\begin{array}{l}3 \\
2\end{array}$ & $\begin{array}{l}\text { Granulocyte } \\
\text { Lymphocyte }\end{array}$ \\
\hline $\begin{array}{l}\text { Chronic granulocytic } \\
\text { leukaemia }\end{array}$ & 3 & $\underline{2}$ & 1 & $\begin{array}{l}\text { Granulocyte } \\
\text { Lymphocyte }\end{array}$ \\
\hline $\begin{array}{l}\text { Chronic lymphocytic } \\
\text { leukaemia }\end{array}$ & 4 & $\begin{array}{l}4 \\
4\end{array}$ & $\overline{-}$ & $\begin{array}{l}\text { Granulocyte } \\
\text { Lymphocyte }\end{array}$ \\
\hline Malignant lymphomas & 5 & $\begin{array}{l}3 \\
1\end{array}$ & $\begin{array}{l}2 \\
4\end{array}$ & $\begin{array}{l}\text { Granulocyte } \\
\text { Lymphocyte }\end{array}$ \\
\hline $\begin{array}{l}\text { Idiopathic aplastic } \\
\text { anaemia }\end{array}$ & 8 & $\begin{array}{l}5 \\
4\end{array}$ & $\begin{array}{l}3 \\
4\end{array}$ & $\begin{array}{l}\text { Granulocyte } \\
\text { Lymphocyte }\end{array}$ \\
\hline $\begin{array}{l}\text { Non-leukaemic } \\
\text { leucocytosis }\end{array}$ & 10 & $\begin{array}{l}7 \\
8\end{array}$ & $\begin{array}{l}3 \\
2\end{array}$ & $\begin{array}{l}\text { Granulocyte } \\
\text { Lymphocyte }\end{array}$ \\
\hline Myeloma & 9 & $\begin{array}{l}1 \\
2\end{array}$ & $\begin{array}{l}8 \\
7\end{array}$ & $\begin{array}{l}\text { Granulocyte } \\
\text { Lymphocyte }\end{array}$ \\
\hline
\end{tabular}

\section{DISCUSSION}

The strongest G.G.T.P. activity was established in kidneys and spleen (Orlowski, 1963). The biochemical role of this enzyme in cells is still unknown (Hanes, Hird, and Isherwood, 1950 and 1952). Investigations showed activity in almost all bone marrow and blood cells, but it was weaker in these cells than in kidneys, since incubation for up to two hours is necessary for blood cells to show enzyme activity whereas in kidney tissue it is visible after only 10 minutes' incubation (Albert et al., 1961; Glenner et al., 1962). It is interesting to note that the enzyme activity is visible in almost all circulating lymphocytes $(63-100 \%)$ in comparison with the low percentage $(2-10 \%)$ in bone marrow lymphocytes. This observation is probably due to two populations of lymphocytes established in blood (Craddock, 1962; Rebuck, Coffmann, Bluhm, and Barth, 1964) which differ in their life span; the first, found in bone marrow, are short lived (about five days) cells, and the second, observed in lymph nodes and peripheral blood are long-lived (about 100 days) lymphocytes (Rebuck et al., 1964). These two types of lymphocyte differ in esterase activity (Ackerman, 1964; Fleischhacker and Stacher, 1964). Demonstration of G.G.T.P. activity also makes possible the differentiation between short- and long-lived lymphocytes.

Decreased G.G.T.P. activity in neoplastic plasma cells, together with previously established changes in A.T.P.-ase and esterase activities (Löffler and Schubert, 1963; Schubert and Rinneberg, 1962), admits of the more accurate histochemical differentiation between normal and neoplastic plasma cells.

\section{REFERENCES}

Ackerman, G. A. (1964). Ann. N.Y. Acad. Sci., 113, 537.

Albert, Z., Orlowski, M., and Szewczuk, A. (1961). Nature (Lond.), 191, 767.

Craddock, C. G. (1962). Progr. Hemat., 3, 92.

Fleischhacker, H., and Stacher, A. (1964). Med. Klin., 59, 382.

Fodor, P. J., Miller, A., Neidle, A., and Waelsch, H. (1953). J. biol. Chem., 203, 991.

Glenner, G. G., Folk, J. E., and McMillan, P. J. (1962). J. Histochem. Cytochem., 10, 481.

Hanes, C. S., Hird, F. J. R., and Isherwood, F. A. (1950). Nature (Lond.), 166, 288.

,,-- (1952). Biochem. J., 51, 25.

Kinoshita, J. H., and Ball, E. G. (1953). J. biol. Chem., 200, 609

Löffler, H., and Schubert, J. C. F. (1963). Klin. Wschr., 41, 484.

Orlowski, M. (1963). Arch. Immunol. Ther. Exp., 11, 1.

Rebuck, J. W., Coffmann, H. I., Bluhm, G. B., and Barth, G. L. (1964). Ann. N.Y. Acad. Sci., 113, 595.

Schubert, J. C. F., and Rinneberg, H. (1962). Blut, 8, 282.

Sullivan, M. X., and Hess, W. C. (1936). J. biol. Chem., 116, 221. 